\title{
Supercomputer 'dumping' dispute heats up
}

Washington. A vote last week in the US House of Representatives has raised the political stakes of a pending decision by the National Science Foundation (NSF) whether to allow the leasing of Japanesemade supercomputers to the National Center for Atmospheric Research (NCAR).

The University Corporation for Atmospheric Research (UCAR), which runs NCAR for the NSF, expects to conclude negotiations "in the near future" to lease four supercomputers built by Japan's NEC Corporation. The supercomputers would be used to run complex climate models. NSF would have to approve any leasing contract.

But the NSF appropriations bill for 1997 passed in the House last week includes a measure sponsored by two House Democrats - David Obey (Wisconsin) and Martin Sabo (Minnesota) - denying salaries to any NSF official who approves the transaction, if the US Commerce Department ultimately finds that NEC is guilty of price "dumping" (see Nature 381, 723; 1996).

That verdict will be slow in coming. Last week, Cray Research, which lost the leasing bid to NEC, had not yet filed a formal complaint of dumping to the Commerce Department. But the company does intend to file a complaint, according to William Bartolone, vice-president for government operations, after which the department would have 20 days to decide whether to launch an investigation. If it does, even a preliminary verdict could take four months.

The department could decide to investigate the matter on its own, although that rarely happens. In a letter last week, Neal Lane, the NSF director, asked Mickey Kantor, the Commerce Secretary, to notify him if the department plans such a "selfinitiated" investigation or if it finds, after reviewing data recently supplied by the NSF, "that its concerns are allayed so that such an investigation is not warranted".

The NSF has twice asked UCAR to look closely at the NEC bid and to confirm that it

\section{Former head of cancer charity arrested}

Paris. Jacques Crozemarie, who was ousted as chairman of France's biggest medical charity, L'Association pour le recherche contre le cancer (ARC), after a financial scandal earlier this year, was last week arrested and indicted on fraud charges.

Denis Baumont and Michel Simon, the heads of two companies that are alleged to have enjoyed privileged contracts from ARC were also arrested in police swoops and remanded in custody; the two companies are alleged to have overcharged the charity by substantial amounts and taken excessive commissions (see Nature 379, 103; 1996). does not include noncompetitive practices. In a statement last week, UCAR said that, after hiring outside consultants to review the bid, it has concluded that "the best and final offer of [NEC] is fair".

The NSF clearly believes, too, that right is on its side. Lined up against it, however, are protectionist forces in Congress. The American Federation of Labor and the presidential gadfly Ross Perot were only two of those who weighed in last week to encourage the House to squash the NEC supercomputer deal.

A recent congressional vote on a Japanese shipbuilding contract, which went in favour of protectionism, was said to be a factor in a decision by Jim Kolbe (Republican, Arizona) to withdraw his amendment deleting the Obey-Sabo clause.

Kolbe did, however, secure a promise that the matter will be debated again before the House and Senate finalize the NSF appropriations bill this autumn.

That gives the NSF at least several weeks to decide whether to approve the NCAR deal, and to ponder the wisdom of bucking what has been an unwritten rule among large federal laboratories - that, when it comes to supercomputers, the only way to buy is American. Tony Reichhardt

\section{French action aims to quell BSE fears}

Paris. France moved swiftly last week to respond to the advice of its scientific advisory committee on bovine spongiform encephalopathy (BSE), spurred by criticism of its failure in early May to respond to the committee's suggestion to act as if BSE can be passed to humans.

Alain Juppé, the prime minister, announced that the government would implement to the letter a series of recommenda- Alain Juppé (right) announces the French measures tions submitted by the commit- on BSE, with agriculture minister Philippe Vasseur. tee just a few hours earlier. These include the following:

- Meat and bone meal should be manufactured only from abattoir wastes considered fit for human consumption, and the practice of processing carcasses of farm and domestic animals should be discontinued.

- There should be a ban on the use of all central nervous system tissues of ruminants both in meat and bone meal, and for human consumption. (In April the government banned human consumption of such tissues from animals born before August 1991.)

- France should ask for its ban on the import of meat and bone meal from the United Kingdom to be extended to all members of the European Union (EU).

- There should be strict separation of feed used for ruminants and that used for other animals, enforced by new tracking systems and better controls.

The high political profile given to the announcement appears to have been part of an attempt by the government to restore public faith in its commitment to openness about BSE. This was damaged last month when the newspaper Le Monde revealed that the BSE advisory committee had advised the government on 9 May to act as if BSE could be trans- mitted to humans, but that the government had decided to keep the report secret until 7 June.

The revelations were particularly embarrassing in that they established that Jacques Chirac, the French president, was aware of this recommendation when in mid-May he promised his support to John Major, the British prime minister, for a partial lifting of the EU ban on UK beef products.

The French government's concern to avoid charges of withholding information from the public is also said to have led it to require a group of researchers to hold a press conference last month about a paper, unpublished at the time (and now published in Nature 381, 743-744; 1996) reporting that macaques inoculated with infected cattle brain developed similar pathological symptoms to humans with the new variant of Creutzfeldt-Jakob disease.

- The French consumer association UFCQue Choisir announced last week that it will bring legal proceedings against ' $X$ ' for the marketing of potentially contaminated meat and bone meal imported from the United Kingdom (see Nature 381, 544; 1996). Jacques Toubon, the justice minister, said that he was considering taking similar action. Declan Butler 